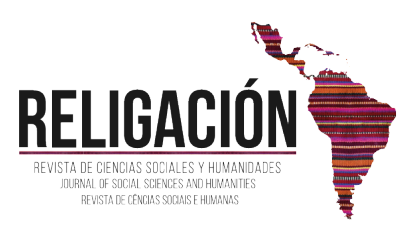

Sección General

\title{
Perception, Gap and Reflection of Service-Oriented Organizational Citizenship Beha- viors from the Perspective of Banking Employees and Customers in Indonesia
}

\author{
Percepción, brecha y reflexión de los comportamientos de ciudadanía organizacional orientados al servicio desde la perspectiva de los em- \\ pleados y clientes bancarios en Indonesia
}

\author{
Soni Harsono | Sekolah Tinggi IImu Ekonomi - INDONESIA | \\ Harry Widyantoro | Sekolah Tinggi IImu Ekonomi - INDONESIA | \\ Program Studi Manajemen, STIE Perbanas Surabaya.E-mail: harry@perbanas.ac.id \\ Tjahjani Prawitowat | Sekolah Tinggi IImu Ekonomi - INDONESIA | \\ Program Studi Manajemen, STIE Perbanas Surabaya. E-mail: tjahjani@perbanas.ac.id \\ Basuki Rachmat | Sekolah Tinggi IImu Ekonomi - INDONESIA | \\ Program Studi Manajemen, STIE Perbanas Surabaya. E-mail: basuki@perbanas.ac.id
}

Corresponding Author. Department of Management, STIE Perbanas, Surabaya, Indonesia. E-mail: soni@perbanas.ac.id

\begin{abstract}
The purpose of this study is to explore perceptions, gaps and relationships between the dimensions of Service-Oriented Organizational Citizenship Behaviors (S-OOCBs) and Service Quality (servqual) in terms of banking employees and customers. This study used a quantitative approach, involving 399 respondents consisting of 74 employees and 325 customers of Bank Perkreditan Rakyat (BPR) and Bank Pembangunan Daerah (BPD). This study proves that the average perception of BPR customers and employees on S-OOCBs and servqual is higher than that of BPD customers and employees. Based on the average gap of perceptions of the dimensions of S-OOCBs and servqual, the customers perceive that the employees have the dimensions of S-OOCBs in the same category as the employees' self-evaluation. According to BPR/BPD employees and customers, all dimensions examined are the reflection of S-OOCBs. The $\mathrm{S}-\mathrm{OOCBs}$ of both employees and customers of BPR and BPD have a significant positive effect on servqual. The results of this study have managerial implications because they are viewed from two sides, banking employees and customers, and are useful for banking management.
\end{abstract}

Keywords: Service Quality (Servqual), Indonesia, Bank Perkreditan Rakyat, Bank Pembangunan Daerah,

RESUMEN: El propósito de este artículo es explorar las percepciones, las brechas y las relaciones entre las dimensiones de los comportamientos de ciudadanía organizacional orientada a servicios (S-OOCB) y servqual en términos de empleados y clientes bancarios. Se utilizó un enfoque cuantitativo, que involucró a 399 encuestados, compuesto por 74 empleados y 325 clientes de Bank Perkreditan Rakyat (BPR) y Bank Pembangunan Daerah (BPD). Este estudio demuestra que la percepción promedio de los clientes y empleados de BPR en S-OOCBs y servqual es mayor que la de los clientes y empleados de BPD. Basado en la brecha promedio de percepciones de las dimensiones de S-OOCBs y servqual, los clientes perciben que los empleados tienen las dimensiones de S-OOCBs en la misma categoría que la autoevaluación de los empleados. Según los empleados y clientes de BPR / BPD, todas las dimensiones examinadas son el reflejo de los S-OOCB. Los S-OOCB de los empleados y clientes de BPR y BPD tienen un efecto positivo significativo en servqual. Los resultados de este estudio tienen implicaciones gerenciales porque son vistos desde dos lados, empleados bancarios y clientes, y son útiles para la gestión bancaria.

Palabras clave: calidad del servicio (Servqual), Indonesia, Bank Perkreditan Rakyat, Bank Pembangunan Daerah 


\section{INTRODUCTION}

The concept of service quality has attracted a lot of attention of academics and practitioners because it is from the service quality that loyalty will be created. Judging from the development of research on service quality, there are several researchers who are made references in conducting research on service quality, such as (Gronroos 1984) with his dimensions of service quality, consisting of technical quality (what the customer gets) and functional quality (how the customer gets), and (Parasuraman, et al. 1988) with his five dimensions of service quality. Meanwhile (Md. Abdul Jalil, et al. 2014) reveals the factors that influence customers to receive Islamic banking services for Muslims, such as products and services, reliability, and availability of outlets. However, for non-Muslims, products and services are the most important factors. Other important factors for them are reliability, availability of outlets and religion. From data analysis, it is found that non-Muslims take sharia or Islamic services not only because of the Islamic brand but also because of several other factors such as service perceived, service convenience, ethical organization.

In addition to service quality and benefits sought, another factor that influences customer satisfaction and loyalty is Organizational Citizenship Behavior (OCB), the behavior shown by employees who carry out not only their obligations and responsibilities, but also something more than those without any reward or anything from the organization and solely for the sake of the organizational goals. The dimensions of OCB are customer facilitation, organizational involvement, and sportsmanship. Kumar (2014), in his research, reveals that the employee's OCB can increase customer satisfaction. Thus, from a marketing perspective, OCB is a special aspect that supports the marketing of services and plays a role in improving services to customers (Sabiote, 2005 and Kumar. 2014). The result of the study conducted by (Jain, Malhotra and Guan. 2012) shows that the behavior outside the role is Service-Oriented Citizenship Behavior (S-OCB) which contributes to the management of relationships between company and customers, shapes customer perceptions of excellent service quality and leads to customer loyalty.

Previous research conducted by (Harsono, Tjahjani, Basuki and Harry. 2017) proves that the highest number of S-OCB dimensions that have a significant effect on service quality is in BPD (6 dimensions) and the second is in BPR. This research raises further questions as to how this S-OCB can be used as a corporate culture that supports employees' services to customers without neglecting their main duties. Therefore, it is necessary to study how to explore the implementation of S-OCB at various levels and how to evaluate the implementation of S-OCB with the hope of creating excellent service quality which is ultimately increasing customer satisfaction and loyalty. Some studies on S-OCB, servqual, satisfaction, and loyalty, including their testing, have been conducted partially. But, this study combines the S-OCB model with servqual which is related to customer satisfaction and loyalty. The urgency of this study is due to the absence of research in the field of Marketing and HRM which combines two models of S-OCB and servqual in BPR and BPD which ultimately create customer satisfaction and loyalty. Based on the description in the previous section, the purpose of this study is to explore perceptions, gaps and the relationship between the dimensions of $\mathrm{S}-\mathrm{OOCBs}$ and servqual from the sides of employees and customers of BPR and BPD in Indonesia.

\section{THEORETICAL RESEARCH DEVELOPMENT OF HYPOTESIS AND MODELS}

Customer loyalty will be shaped if the service quality is applied consistently. (Gronroos.1984) reveals that the dimensions of service quality consist of (1) technical quality; what the customer get (2) functional quality; how the customers get. In addition, (Garvin. 1984) reveals that in order to shape customer loyalty, the service quality needs to be implemented properly by management, and the dimensions of the service quality include (1) performance; (2) features; (3) reliability; (4) conformance; (5) durability; (6) serviceability; (7) aesthetics; and (8) perceived quality. According to Parasuraman, et al. (1985), service quality consists of ten dimensions, namely (1) reliability; (2) responsiveness; (3) competence; (4) access (5) politeness; (6) communication; (7) credibility; (8) security; (9) the ability to understand customers; and (10) physical evidence. In its development, as the concept of service quality was applied in various sectors that had different characteristics and different research results, Parasuraman, et al. (1988) modified the concept of service quality derived from previous research by summarizing from ten to five dimensions of service quality, namely: (1) responsiveness; (2) assurance; (3) empathy; (4) tangible and (5) reliability.

In subsequent developments, many researchers conducted research on service quality with different models and measurements as well as different service sectors. Cronin and Taylor (1992) state that service quality is measured by a Service Performance (SERVPERF) scale using the SERVQUAL dimension. Furthermore, (Rust and Oliver. 1994) state that service quality is measured using three dimensions, namely (1) service product; (2) service delivery and (3) service environment. There are only few studies on service quality conducted in banking sector. One of them is by (Parasuraman et al., 1988) using 5 dimensions of SERVQUAL, namely tangible, reliability, responsiveness, empathy, and assurance. It was then followed by (Cronin and Taylor, 1992) using 5 dimensions of SERVQUAL with the name SERVPERF, namely tangible, reliability, responsiveness, empathy, and assurance. The next by (Jamal Ahmad and Kyriaki Anastasiadou, 2009) using 5 dimensions of SERVQUAL, namely tangible, reliability, responsiveness, empathy, and assurance. The next research was conducted by (Siddiqi Omar Kazi, 2011) using 5 dimensions of SERVQUAL, namely tangible, reliability, responsiveness, empathy, and assurance. 
Some of the above studies have caused a lot of debate about the limitations of the service quality (SERVQUAL) model, considering that service quality has multi dimensions. So, in order to solve these problems, (Brady and Cronin, 2001) suggest the need to understand the main dimensions as an alternative to the dimensions of service quality. The dimensions are interaction quality, a contact that occurs in the process of delivering services between service providers and consumers, environment quality and outcome quality. Specifically, (Gronroos, 2000) emphasizes that interaction quality is the quality that is closely related to how the service process is delivered, which is seen from the interaction process between service provider staff and its customers.

Apart from the debate about the dimensions of service quality, there is one thing that becomes the meeting point of the research, that is, the service quality from one organization or company to another organization or company varies greatly. This is due to the differences in operational aspects, organizational culture, local or regional culture, and scope, such as local, domestic or international.

An organization expects to have employees who are committed to the organization by giving extra contributions outside of basic duties and obligations, such as serving customers not only during working hours, willing to carry out tasks outside of regular working days and hours without expecting rewards, promoting the company to other parties considered bringing benefits to the company. According to (Organ, 2006), Organizational Citizenship Behavior (OCB) is voluntary behavior by employees, with no formal reward system, and that behavior supports the effectiveness and efficiency of the organization. With regard to services to customers, all things done by employee, which are above the expectations of service standards from the company, will certainly lead to customer satisfaction. The results of the research conducted by (Kumar, 2014) reveals that OCB from employees can increase customer satisfaction.

From a marketing perspective, OCB is a special aspect that supports the marketing of services and plays a role in improving services to customers (Sabiote. 2005; Kumar. 2014). The results of previous research (Jain et al., 2012) show that the behavior outside the role is Service-Oriented Citizenship Behavior (S-OCB) which contributes to the management of the relationships between company and customers, shapes customer perceptions of excellent service quality and can lead to customer loyalty. Subsequent research conducted by (Jain, et al., 2014) concludes that there are three dimensions of S-OCB, namely employee loyalty, service, and participation that can shape customer loyalty. Research on OCB from the perspective of the customers, particularly bank customers, was carried out by (Sabiote and Roman, 2005) by developing the OCB instrument from the perspective of customers. The dimensions of OCB in this study are customer facilitation, organizational involvement, and sportsmanship. Referring to the background of the problem and theory, the hypothesis proposed in this study are: Hypotesis 1: Employees' perception of S-OOCBs has a higher average than perceptions of banking customers. Hypotesis 2: Employee perceptions of service quality have a higher average than perceptions of banking customers. Hypotesis 3: There is a balance between employee perceptions and customers of banking S-OOCBs. Hypotesis 4: There is a gap between employee and customer perceptions of the quality of banking services. Hypotesis 5: S-OOCBs has a significant positive effect on service quality from the perspective of Indonesia employees and banking customers.

\section{METHODOLOGY}

This study used a quantitative approach and adopted SERVQUAL instruments from (Parasuraman et al., 1988) consisting of: tangibles, reliability, assurance, empathy, and responsiveness with twenty-two (22) question items. This study also adopted the dimensions of S-OOCBs from (Bettencourt, Gwinner and Meuter. 2001); (Mei-Ling Wang, 2009); (Payne and Weber. 2006); (M.A Farrell and E. Oczkowski, 2009); (X. Deng, Tawei \& Robert. 2015) and (Seigyong, Bulent, Yeon. 2014), namely loyalty (L), service delivery (SD), service orientation (SO), altruism (A), the need to pay attention to customer (NAC), the need to know customers' needs (NKCN), the need for personal relationships (NRP), education OCB (EOCB), anticipation OCB (AOCB), justification OCB (JOCB), personalization-technology OCB (PTOCB) and Altruism (AL). This research instrument consists of five main parts, namely (1) demographic profile, which includes four questions; (2) SERVQUAL instrument; (3) S-OOCBs instrument and (5) open questions. The research instrument is measured using a six-point Likert scale. The samples in this study were employees and customers of Bank Perkreditan Rakyat (BPR) and Bank Pembangunan Daerah (BPD). The data of this study were collected through questionnaires distributed to 399 respondents consisting of 34 employees and 123 customers of BPR and 40 employees and 202 customers of BPD. Data analysis in this study was done using WarpPLS.

\section{RESULT AND DISSCUSION}

The variable of service-oriented organizational citizenship behavior (S-OOCBs) in BPR, the customer respondents give a positive response to 41 (forty-one) indicators of statements examined. The mean value of S-OOCBs as a whole is 5.7178 of the scale 6. Based on the predetermined average variables, the assessment of customer respondents is included in category of strongly agree with the S-OOCBs indicator they perceive as long as they interact with BPR. 
The variable of service quality in BPR, the customer respondents give a positive response to the 21 (twenty-one) indicators of statements examined. The mean value of service quality as a whole is 5.2484 of the scale 6. Based on the predetermined average variables, the assessment of customer respondents' is included in category of strongly agree with the indicator of service quality that customers perceive as long as they interact with BPR. The variable of service-oriented organizational citizenship behavior (S-OOCBs) in BPR, the employee respondents give a positive response to the 49 (forty-nine) indicators of statements examined. The mean value of S-OOCBs as a whole is 5.2703 of the scale 6. Based on the predetermined average variables, the assessment of employee respondents is included in category of strongly agree with the indicator of S-OOCBs that employees perceive as long as they work at BPR. The variable of service quality at BPR, the employee respondents give a positive response to the 22 (twenty-two) indicators of statements examined. The mean value of service quality as a whole is 5.1441 of scale 6 . Based on the predetermined average variables, the assessment of employee respondents is included in category of agree with the indicators of the service quality that employees perceive as long as they work at BPR Modern Express Ambon. The S-OOCBs dimensions are also seen from the gap between the perceptions of customers and the perceptions of employees of BPR as in Table 1.

Table 1. The Average Gap between Customers' Perception and Employees' Perception to S-OOCBs Dimensions in BPR

\begin{tabular}{|c|c|c|c|}
\hline $\begin{array}{c}\text { S-OOCBs } \\
\text { Dimension }\end{array}$ & $\begin{array}{c}\text { Perception of cus- } \\
\text { tomer/ } \\
\text { Category }\end{array}$ & $\begin{array}{c}\text { Perception of Employ- } \\
\text { ee/ } \\
\text { Category }\end{array}$ & Gap \\
\hline L & $5.29 / \mathrm{SA}$ & $5.58 / \mathrm{SA}$ & 0.29 \\
\hline SD & $5.38 / \mathrm{SA}$ & $5.47 / \mathrm{SA}$ & 0.09 \\
\hline SO & $5.32 / \mathrm{SA}$ & $5.52 / \mathrm{SA}$ & 0.20 \\
\hline NAC & $5.17 / \mathrm{SA}$ & $5.29 / \mathrm{SA}$ & 0.13 \\
\hline NKCN & $5.14 / \mathrm{S}$ & $4.93 / \mathrm{S}$ & -0.21 \\
\hline NRP & $5.19 / \mathrm{SA}$ & $5.28 / \mathrm{SA}$ & 0.09 \\
\hline EOCB & $5.36 / \mathrm{SA}$ & $5.38 / \mathrm{SA}$ & 0.02 \\
\hline AOCB & $5.17 / \mathrm{SA}$ & $5.26 / \mathrm{SA}$ & 0.09 \\
\hline JOCB & $5.28 / \mathrm{SA}$ & $5.18 / \mathrm{SA}$ & -0.11 \\
\hline PBOCB & $5.30 / \mathrm{SA}$ & $5.21 / \mathrm{SA}$ & -0.09 \\
\hline PTOCB & $5.13 / \mathrm{S}$ & $4.91 / \mathrm{S}$ & -0.22 \\
\hline Altruism & $5.23 / \mathrm{SA}$ & $5.21 / \mathrm{S}$ & 0.02 \\
\hline SOCB & $5.25 / \mathrm{SA}$ & $5.27 / \mathrm{SA}$ & 0.02 \\
\hline
\end{tabular}

Table 1 describes the existence of an average gap between customers' perception and employees' perception to each dimension of S-OOCBs in BPR. In all dimensions, customers perceive that the employees have the S-OO$\mathrm{CBs}$ dimensions in the same category as the self-evaluation of the employees themselves (in category of good and very good), even though there are differences in mean values. The negative (minus) gap means that the mean value of the customer is smaller than that of the employee (self employee), while the positive (plus) gap means that the mean value of the customer is greater than that of the employee (self employee). Negative gaps exist in the dimensions of loyalty (L), service delivery (SD), service orientation (SO), the need to pay attention to customers (NAC), the need to establish personal relationships (NRP), educating customers (EOCB), and anticipating constraints (AOCB). Meanwhile, positive gaps exist in the dimensions of the Need to Know Customer Needs (NKCN), Problem Justification (JOCB), Personalization in Business (PBOCB), Technology Personalization (PTOCB), and Altruism (AL). The average perception of $\mathrm{S}-\mathrm{OOCB}$ s variables in BPR on customers and employees is in the excellent category with a slight difference in mean values (-0.02). Thus, it can be concluded that according to customers, in general, the S-OOCBs of employees of BPR are in the category of excellent. However, there are dimensions that still need attention, that is, Loyalty and Orientation to Services. Analysis on the dimensions of service quality which is seen from the gap between the perception of customer and the perception of employees of BPR is shown in Table 2. 
Table 2. Average Gap between the Perception of Customers and the Perception of Employees of BPR to Service Quality

\begin{tabular}{|c|c|c|c|}
\hline $\begin{array}{c}\text { Dimension of } \\
\text { Service Quality }\end{array}$ & $\begin{array}{c}\text { Perception of Cus- } \\
\text { tomers/ } \\
\text { Category }\end{array}$ & $\begin{array}{c}\text { Perception of } \\
\text { Employees/ } \\
\text { Category }\end{array}$ & Gap \\
\hline TA & $5.03 / \mathrm{S}$ & $4.99 / \mathrm{S}$ & 0.04 \\
\hline $\mathrm{RI}$ & $5.27 / \mathrm{SA}$ & $5.27 / \mathrm{SA}$ & 0.00 \\
\hline $\mathrm{RS}$ & $5.33 / \mathrm{SA}$ & $5.26 / \mathrm{SA}$ & 0.07 \\
\hline $\mathrm{AS}$ & $5.37 / \mathrm{SA}$ & $5.11 / \mathrm{S}$ & 0.26 \\
\hline $\mathrm{EM}$ & $5.23 / \mathrm{SA}$ & $5.08 / \mathrm{S}$ & 0.15 \\
\hline $\mathrm{KL}$ & $5.25 / \mathrm{SA}$ & $5.14 / \mathrm{S}$ & 0.10 \\
\hline
\end{tabular}

Table 2 describes the existence of an average gap between the perception of customers and the perception of employees of BPR in each dimension of Service Quality. In the dimensions of TA, RI, and RS, customers perceive that employees have a dimension of Service Quality in the same category as self-evaluation from its own employees (in the category of good for TA and Very Good for RI, RS), although there are differences in mean values. The negative (minus) gap, which means the mean value of the customer is less than the mean value of the employee (self-employee), does not exist in the condition of the BPR. Meanwhile, the positive (plus) gap, which means the mean value of the customer is greater than the mean value of the employee (self-employee), exists in the dimensions of TA, RS, AS, EM, KL. Differences in categories are in the US, EM, and KL dimensions, where customers perceive that BPR employees to be in category of very good on the dimensions of service quality, while the assessment of the employees themselves is in category of good. Average customer perceptions of service quality variable in BPR are in category of excellent, while according to employees, it is in the category of good with a difference in mean values of 0.10 . Thus, it can be concluded that according to customers, in general the service quality of BPR employees is in category of very good. Having stated that the results of the fit index meet the requirements, the following are the results of testing the model for the dimensions of the variable of S-OOCBs and the effect of S-OOCB on service quality (servqual) on employees of BPR.

Figure 1 is a reflective model reflecting that each indicator is a measurement of errors imposed on latent variables. The cause and effect direction is from the latent variable to the indicator so that the indicators are a reflection of the variation of the latent variable. Therefore, Figure 1 can be explained as follows:

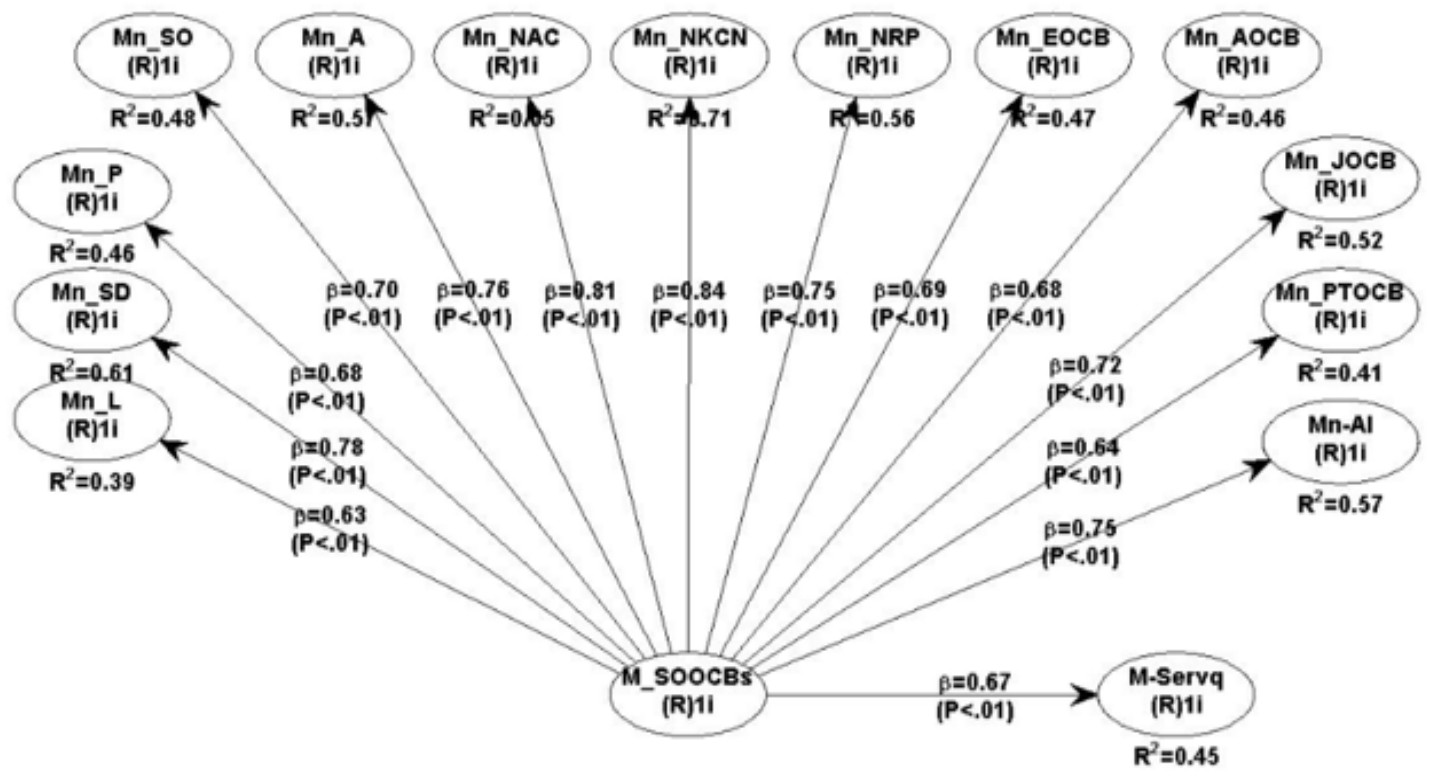

Figure 1. Full Model of S-OOCBs - Servqual of BPR Employees 
From the output in Figure 1 it can be concluded that the S-OOCBs of the employeesof BPR are manifested by dimensions of loyalty $(L)$, service delivery $(S D)$, participation $(P)$, serviceorientation $(S O)$, altruism (A), the need to pay attentionto customer ( NAC), the need to know customers' needs (NKCN), the need for personal relationships (NRP), education OCB (EOCB), anticipation OCB (AOCB), justification OCB (JOCB), personalization-technology OCB (PTOCB) and altruism (AL) because the loading factor value is above 0.50 and $p<0.01$. The effect of $S-O O C B s$ on service quality (servqual) is shown in Figure 1. It can be concluded that the S-OOCBs of the employees of BPR have a significant positive effect on service quality (servqual), evidenced by the coefficient value $=0.67 ; p<0.01$ or $p<0.05$ Figure 2 below is the result of model test for the dimensions of S-OOCBs variable and the effect of S-OOCBs on service quality (servqual) on the customers of BPR.

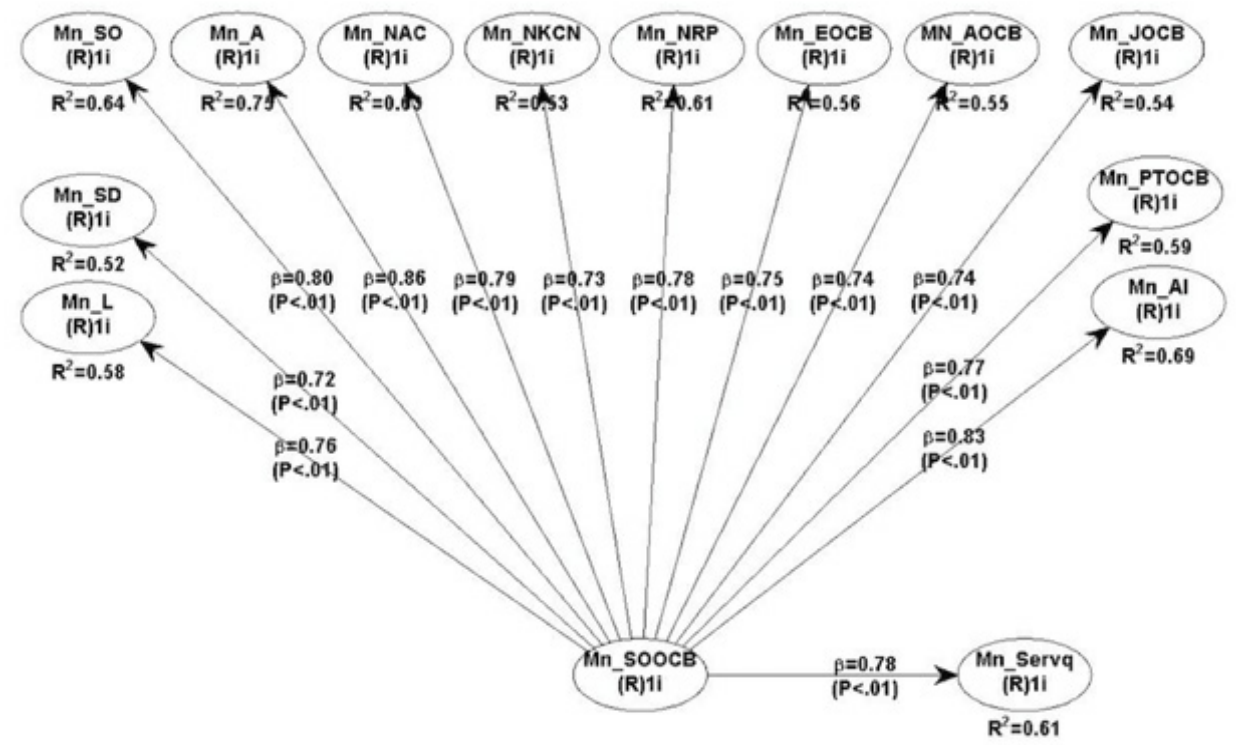

Figure 2. Full Model of S-OOCBs - Servqual of BPR customers.

From the output in Figure 2 it can be concluded that the S-OOCBs of the customers of BPR are manifested by dimensions of loyalty (L), service delivery (SD), service orientation (SO), altruism (A) Payne \& Weber (2006), the need to pay attention to customer (NAC), the need to know customers' needs (NKCN), the need for personal relationships (NRP), education OCB (EOCB), anticipation OCB (AOCB), justification OCB (JOCB), personalization-technology OCB (PTOCB) and Altruism (AL) because the loading factor value is above 0.50 and $p<0.01$.

The influence of S-OOCBs on service quality (servqual) is shown in Figure 2. It can be concluded that the $\mathrm{S}-\mathrm{OOCBs}$ of the customers of BPR have a significant positive effect on service quality (servqual), as evidenced by the coefficient $=0.78 ; \mathrm{p}<0.01$ or $\mathrm{p}<0.05$.

\section{CONCLUSION}

The mean value of the perception of the customers of BPR on S-OOCBs is higher than that of the customers of BPD. The mean value of the perception of the customers of BPR on service quality (servqual) is higher than that of the customers of BPD. The mean value of the perception of the employees of BPR on S-OOCBs is higher that of the employees of BPD. The mean value of the perception of the employees of BPR on service quality (servqual) is higher than that of the employees of BPD.

The average gap between the perception of customers and the perception of employees of BPR to the $\mathrm{S}-\mathrm{OOCBs}$ dimension shows that customers perceive that employees have the S-OOCBs dimension in the same category as the employee's own self-evaluation (in the category of good and very good) although there are differences in mean values. The average gap between the perception of customers and the perception of employees of BPR to service quality (servqual) with the dimensions of tangibles (TA), reliability (RI), and responsiveness (RS), customers perceive that employees have servqual dimension in the same category as the employees' self-evaluation (in the category of good for TA and very good for RI, RS) although there are differences in the mean values.

The mean value of the perception of the customers and employees of BPD on S-OOCBs variable is category of good with a difference in mean value of 0.13 , which means that the assessment of customers is higher than that of 
employees themselves. The mean value of the perception of the customers and employees of BPD on service quality (servqual) variable is in category of good with a difference in mean value of 0.08 , which means that, according to customers, generally the service quality (servqual) of BPD employees is in the category of good.

The coefficient value shows that the S-OOCBs of the employees of BPD have a significant positive effect on service quality (servqual) in BPD. The coefficient value shows that the S-OOCBs of the customers of BPD have a significant positive effect on service quality (servqual) in BPD.

\section{SUGGESTION}

Since the perception of customers and employees of BPR on S-OOCBs and service quality (servqual) has a mean value higher than that of BPD, researchers suggest to maintain all dimensions of S-OOCBs and quality service (servqual) that have high mean values and improve the dimensions that have still low mean values. Since the perception of customers and employees of BPD on S-OOCBs and service quality (servqual) has a mean value lower than that of BPR, researchers suggest to evaluate all dimensions, especially those that have low mean values, and the gap between employees and customers.

Although the average gap between the perception of customer and the perceptions of employees of BPR towards S-OOCBs is not much different (in the category of good and very good), researchers suggest that the management of BPR conduct employee self-evaluation by looking back on a very low mean value that has the potential to reduce the desire of employees to do work outside of their duties with pleasure.

Although the average perception of customers and employees toward S-OOCBs is in category of good, moreover when the assessment of customers is higher than the assessment of employees, it does not mean that there is no problem. The problem exists in the BPD employees themselves, that is, do not ever feel complacent, because the customer's assessment is better than self-assessment. One thing that should be done is to re-evaluate the customers' low assessments toward S-OOCBs and find the root of the problem.

The average perception of the variable of service quality at BPD, according to customers and employees, is in category of good, but the factor that needs to be considered is the lowest mean value of Empathy (EM), which is contradictory to the assessment of customers toward S-OOCBs in category of good, that is, the employee's willingness to do work outside his main task. It is suggested to re-evaluate the dimension of the need to know customers' needs (NKCN) which has the lowest mean value.

\section{LIMITATION}

This study focuses on S-OOCBs and service quality from the perspective of employees and customers of BPR and BPD, thus impacting on the limited generalization of research. In other words, the scope is limited only in banking as a model. This aspect shows that in applying this research in different contexts, there should be caution in examining the characteristics of the objects under study. Another limitation in this study is that this study only uses one category of banking so that it is difficult to obtain the right conclusion for all categories of banking.

\section{ACKNOWLEDGEMENT}

We would like to thank the Directorate of Research and Community Service (DRPM) of the Ministries of Research, Technology, and Higher Education for the assistance of the PTUPT grant, Rector of STIE Perbanas, Mr. Dr. Lutfi., SE., M.Fin, Chair of the Center for Research and Community Service, Mrs. Dr. Rr. Irmani., M.Sc., Customers, Heads, and Employees of BPD Bali and BPR Modern Express Ambon. 


\section{BIBLIOGRAPHIC REFERENCES}

Ahmad Jamal, Kyriaki Anastasiadou. (2009). Investigating the effects of service Quality dimensions and expertise on loyalty, European Journal of Marketing, Vol. 43 Iss: 3/4, pp.398 - 420

Bettencourt, L. A. (1997). Customer voluntary performance: Customers as partners iservice delivery. Journal of Re-tailing, 73, 383-406

Brady, Michael K., and J. Joseph Cronin. (2001). Some Thought on Conceptualizing Perceived Service Quality a Hierarchical Approach. Journal of Marketing, Vol 63- 34- 39

Bulent Menguc, Seigyoung Auh, Constantine S. Katsikeas, and Yeon Sung Jung. (2016). When Does (Mis) Fit in Customer Orientation Matter for Frontline Employees' Job Satisfaction and Performance?Journal of Marketing: January 2016, Vol. 80, No. 1, pp. 65-83. https://doi.org/10.1509/jm.15.03

Cronin Jr, J. Joseph J., and Steven A. Taylor. (1992). Measuring Service Quality: A Reexamination and Extention. Journal of Marketing, Vol. 56 (July), pp. $55-68$.

Deng, Xuefei (Nancy \& Wang, Tawei. (2014). Understanding Post-Implementation Support for Enterprise Systems: An Empirical Study of IT Personnel's Customer-Oriented Citizenship Behaviors. Journal of information systems. American Accounting Association. Vol. 28, No. DOI: 10.2308/isys-50743.Fall 2014.pp. 17-39.

Farrell, M. A., \& Oczkowski, E. 2009. Service worker customer orientation, organization/job fit and perceived organizational support. Journal of Strategic Marketing, 17 (2), 149-16. doi:10.1080/09652540902879276.

Garvin, David A. (1984). "What Does 'Product Quality' Really Mean?" Sloan Management Review, 26 (Fall), 25-43.

Gronroos, C. (1984). A Service Quality Model and its Market Implications, European Journal of Marketing, Vol. 18. No. 4, pp. 36-44.

Gronroos, C. (2000). Service Management and Marketing: A Customer Relationship Management Approach. 2nd ed. West Sussex: John Wiley \& Sons, Ltd.

Harsono S., Widyantoro H., Prawitowati T., Rahmat B. (2017).The Development of Service Quality Model as A Criterion in Selecting the Banks in Indonesia. Polish Journal of Management Studies 2017; 15 (2): 82-92.

Jain, Ajay K, Naresh K. Malhotra, Chong Guan. (2012). Positive and Negative Affectivity as Mediators of Volunteerism and Service-Oriented Citizenship Behavior and Customer Loyalty. Psychology and Marketing, Vol. 29 (12), pp. 1004-1017.

Kumar, YLN. (2014). Importance of Organizational Citizenship Behaviors in Enhancing Customer Service Indicators: A Review. The IUP Journal of Management Research, Vol. XIII, No.1, pp. 17-28.

Md. Abdul Jalil and Muhammad Khalilur Rahman. (2014). The Impact of Islamic Branding on Consumer Preference towards Islamic Banking Services: An Empirical Investigation in Malaysia. Journal of Islamic Banking and Finance, March, Vol. 2, No. 1, pp. 209-229.

Mei-Ling Wang. (2009). What makes a good citizen in service settings? The Service Industries. Journal. Vol. 29, No. 5, May 2009, 621-634. DOI: 10.1080/02642060902720055

Organ, D.W., Podsakoff, P.M., \& MacKenzie, S.B. (2006). Organizational Citizenship Behavior: Its Nature, Antecedents and Consequences. Thousand oaks, CA: Sage.

Parasuraman, A., Valerie A. Zethaml, and Leonard I. Berry. (1988). SERVQUAL A Multiitem Scale for Measuring Consumer Perceptions of service Quality. Journal of Retailing, Vol. 65 (1): 12 - 36

Payne Stephanie C., and Webber Sheila Simsarian. (2006). Effects of Service Provider Attitudes and Employment Status on Citizenship Behaviors and Customers' Attitudes and Loyalty Behavior. Journal of Applied Psychology, Vol. 91, No. 2, 365-378. Journal of Information Systems. Fall 2014, Vol. 28, No. 2, pp. 17-39

Sabiote, Estela Fernandez and Sergio Roman. (2005). Organizational Citizenship Behavior from the Service Customer's Perspective. International Journal of Market Research, vol.46 Quarter 3, pp. 317-336.

Siddiqi Kazi Omar. (2011). Interrelations Between Service Quality Attributes, Customer Satisfaction and Customer Loyalty in the Retail Banking Sector in Bangladesh. International Journal of Business and management. Vol. 6. No. 3.

How to cite this article: Harsono, S., Widyantoro, H., Prawitowati, T., \& Rachmat, B. (2020). Perception, Gap and Reflection of Service-Oriented Organizational Citizenship Behaviors from the Perspective of Banking Employees and Customers in Indonesia. Religación. Revista De Ciencias Sociales Y Humanidades, 5(23), 118-125. Retrieved from http://revista.religacion.com/ index.php/religacion/article/view/605

Submitted: 06 December 2019 Accepted: 17 March 2020 Published: 31 March 2020

Religación. Revistais de Ciencias Sociales y Humanidades is a peer-reviewed open access journal published by CICSH-AL Centro de Investigaciones en Ciencias Sociales y Humanidades desde América Latina |Religación| 